\title{
Biologi dan statistik demografi Thrips parvispinus Karny (Thysanoptera: Thripidae) pada tanaman cabai (Capsicum annuum Linnaeus)
}

\author{
Biology and demographic statistic of Thrips parvispinus Karny \\ (Thysanoptera: Thripidae) in chili pepper (Capsicum annuum Linnaeus)
}

\author{
Rudi Tomson Hutasoit*, Hermanu Triwidodo, Ruly Anwar
}

${ }^{1}$ Departemen Proteksi Tanaman, Fakultas Pertanian, Institut Pertanian Bogor Jalan Kamper, Kampus IPB Dramaga, Bogor 16680

(diterima Mei 2016, disetujui September 2017)

\begin{abstract}
ABSTRAK
Thrips parvispinus Karny (Thysanoptera: Thripidae) merupakan hama penting pada tanaman cabai di Indonesia. Hama ini dapat ditemukan pada semua bagian tanaman, khususnya bunga dan daun. Informasi mengenai biologi dan statistik demografi T. parvispinus masih terbatas. Oleh karena itu, penelitian ini bertujuan untuk mempelajari biologi dan statistik demografi serangga hama ini. Sebanyak 50 individu nimfa instar ke-1 dipelihara pada daun cabai dalam kurungan serangga yang terbuat dari gelas plastik $(\mathrm{d}=4 \mathrm{~cm}$ dan $\mathrm{t}=8 \mathrm{~cm})$. Perkembangan, individu yang hidup dan mati, dan jumlah telur yang diletakkan setiap imago dicatat setiap hari. Pergantian instar ditandai dengan adanya eksuvia. Data yang terkumpul digunakan untuk mendapatkan informasi biologi, seperti perkembangan setiap instar, periode praoviposisi, siklus hidup, lama hidup imago, dan fekunditas. Data hasil pengamatan kemudian disusun dalam bentuk neraca kehidupan untuk mendapatkan data statistik demografi dengan menggunakan metode Jackknife. Hasil penelitian menunjukkan bahwa, tahap perkembangan pradewasa terdiri atas 5 fase, yaitu telur, 2 stadia nimfa, prapupa, dan pupa dengan rataan perkembangan berturut-turut selama 4,79, 1,36, 3,54, 1,08, dan 1,96 hari. Rataan masa praoviposisi, siklus hidup, lama hidup imago, dan fekunditas berturut-turut adalah 1,11 hari, 13,68 hari, 8,55 hari (betina), 6,00 hari (jantan), dan 15,33 telur. Kurva kesintasan T. parvispinus merupakan kurva tipe III dengan laju pertambahan intrinsik (r) 0,16 individu per imago betina per hari, laju reproduksi bersih $\left(\mathrm{R}_{0}\right) 5,71$ individu per induk per generasi, lama generasi $(\mathrm{T})$ dan waktu berlipat ganda (DT) 11,49 hari dan 4,57 hari.
\end{abstract}

Kata kunci: neraca kehidupan, populasi, siklus hidup

\begin{abstract}
Thrips parvispinus Karny (Thysanoptera: Thripidae) is one of the major pests of chili pepper in Indonesia. The pest can be found on all parts of the plants, especially flowers and leaves. Information of the biology and demographic statistic of T. parvispinus are still limited. The objective of this research was to study the biology and demographic statistic of T. parvispinus in Bogor. Fifty individual of $1^{\text {st }}$ instar nymphs were reared on caged chili pepper leaves $(\mathrm{d}=4 \mathrm{~cm}$ and $\mathrm{h}=8 \mathrm{~cm})$. Chilli pepper leaves were replaced everyday and observed daily to determine the development and number of offspring eggs. The collected data were used to obtain information about the biology of the pest such as the stadia of each instar, preoviposition period, life cycle, adult longevity, and fecundity. The data were also used to construct life tables for demographic statistic analysis using of the Jackknife method. There were 5 phases of immature stages of T. parvispinus: eggs, two instars nymph, prepupa, and pupa with their stadia were $4,79,1,36,3,54,1,08$, and 1,96 days respectively.
\end{abstract}

*Penulis korespondensi: Rudi Tomson Hutasoit. Departemen Proteksi Tanaman, Fakultas Pertanian, Institut Pertanian Bogor Jalan Kamper, Kampus IPB Dramaga, Bogor 16680, Tel: 08129743 7600, Email: ruudhoetasoeit@gmail.com 
The preoviposition period of the insect was 1,11 days, life cycle was 13,68 days, female longevity was 8,55 days, male longevity was 6,00 days, and fecundity was 15,33 eggs per female. The population development of $T$. parvispinus followed type III of survivorship curve with intrinsic rate of increase was 0,15 individual per days female per days, net reproductive rate was 5,71 individual per female per generation, generation time was 11,49 days and doubling time was 4,57 days.

Key words: life cycle, lifetable, population

\section{PENDAHULUAN}

Trips merupakan serangga berukuran kecil dengan panjang tubuh $0,5-5 \mathrm{~mm}$. Panjang tubuh beberapa spesies di daerah tropika dapat mencapai $14 \mathrm{~mm}$ (Borror et al. 1996; Antonelli 2003). Trips umumnya ditemukan pada bagian bunga dan daun tanaman (Mound \& Collins 2000). Peranan trips sebagai hama pada tanaman disebabkan oleh aktivitas makannya (meraut-menghisap). Gejala kerusakan yang ditimbulkan berupa bercak keperakan yang menjadi kecoklatan pada daun yang dapat mengganggu proses fotosintesis, daun mengeriting, dan tunas terminal menjadi kerdil (Kirk 2001). Trips pada tanaman juga dapat berperan sebagai vektor virus (Rezende et al. 1997; Riley et al. 2011). Jenis virus yang ditularkan oleh serangga ini diantaranya Tomatto spotted wilt virus (TSWV), Lettuce spotted wilt virus (LSWF), Pineapple yellolv spotted virus (PYSV), Tip chlorosis, Kromneck diseases, dan Tobacco mosaic virus (TMV) (Klose et al. 1996; Sartiami 2008).

Keperidian yang tinggi dan siklus hidup yang singkat merupakan faktor penting yang menyebabkan terjadinya kolonisasi dan perkembangan populasi trips yang besar di lapangan. Imago betina mampu menghasilkan 30-300 telur bergantung pada spesies dan kualitas nutrisinya (Lewis 1973; Lewis 1997). Perkembangbiakan trips dapat mencapai 12-15 generasi setiap tahunnya pada daerah tropis atau di rumah kaca (Lewis 1973; Mound 2006).

Trips mampu menguasai suatu habitat dalam rentang waktu yang singkat secara optimal. Trips merupakan serangga oportunis dengan tipe seleksi r, waktu generasi pendek, toleransi terhadap kisaran inang yang luas, cenderung partenogenesis, dan struktur perkembangbiakan yang kompetitif sehingga menyebabkan terjadinya agregasi (Funderburk 2001). Menurut Sastrosiswojo (1991), meskipun permasalahan trips di Indonesia dinilai cukup penting, namun 108 tidak banyak penelitian yang telah dilakukan sehingga informasi mengenai serangga ini masih sangat terbatas.

Vos (1991) menyatakan bahwa dari hasil survei Vierbergen tentang hama-hama tanaman cabai di Jawa pada tahun 1988, spesies Thrips parvispinus Karny ditemukan paling dominan pada pertanaman cabai. Imago betina berukuran 0,99-1,35 mm dengan variasi warna coklat muda sampai dengan coklat tua (Prabaningrum 2005). Serangga ini merupakan hama penting pada tanaman cabai dan bersifat polifag. Tanaman inangnya antara lain Crotalaria, Vigna, kopi, mentimun, ubi jalar, tembakau, dan tanaman inang utamanya adalah cabai di pulau Jawa (Kalshoven 1981). T. parvispinus dapat ditemukan pada semua bagian tanaman, terutama bunga dan daun. Spesies lain yang ditemukan menyerang pertanaman cabai adalah Thrips hawaiiensis (Morgan), Thrips florum Schmutz, dan Thrips orientalis (Bagnall).

Mengingat pentingnya peranan serangga ini sebagai hama utama dan vektor penyebaran penyakit pada pertanaman cabai maka perlu diketahui biologi dan aspek demografi dari hama ini. Statistik demografi merupakan salah satu langkah awal dalam mempelajari pertumbuhan populasi serangga. Hal tersebut dapat dilakukan dengan merancang neraca kehidupan (life table). Neraca kehidupan merupakan tabel data kesintasan dan fekunditas setiap individu dalam suatu populasi (Rockwood 2006). Neraca kehidupan dapat memberikan informasi secara terperinci mengenai kelahiran, perkembangan, reproduksi, dan kematian setiap individu dalam suatu populasi atau dengan kata lain memberi gambaran mengenai laju pertumbuhan suatu populasi.

Neraca kehidupan dapat menghasilkan ringkasan statistik sederhana termasuk harapan hidup individu. Selain itu, neraca kehidupan memiliki bentuk dasar yang dapat dimodifikasi untuk berbagai macam analisis data, seperti mortalitas yang disebabkan oleh beragam faktor (Carey 2001). Pendugaan laju pertumbuhan suatu populasi 
dan informasi biologi dapat digunakan sebagai bahan pertimbangan dalam upaya pengendalian serangga hama ini. Dengan demikian, penelitian ini bertujuan untuk mempelajari dan mendapatkan informasi biologi dan statistik demografi $T$. parvipinus pada tanaman cabai.

\section{BAHAN DAN METODE}

\section{Lokasi penelitian}

Pengamatan kohort trips dilaksanakan di Laboratorium WiSH, Batuhulung, Bogor. Identifikasi trips dilakukan di Laboratorium Biosistematika Serangga, Departemen Proteksi Tanaman, Fakultas Pertanian, Institut Pertanian Bogor. Penelitian berlangsung dari Juni 2015 sampai Februari 2016. Selama penelitian berlangsung, rata-rata suhu harian dan kelembaban relatif di dalam laboratorium berturut-turut $27^{\circ} \mathrm{C}$ dan $\pm 87 \%$.

\section{Persiapan tanaman inang}

Tanaman cabai yang digunakan untuk perbanyakan dan pemeliharaan kohort trips berumur 30 sampai 60 hari setelah tanam (HST). Tanaman dipelihara dalam kurungan yang terbuat dari kain kasa organdi. Pemeliharaan tanaman cabai pada kurungan bertujuan untuk menghindari serangan dan infestasi telur dari serangga lain.

\section{Perbanyakan serangga uji}

T. parvispinus yang digunakan sebagai populasi awal dikumpulkan dari pertanaman cabai di Desa Cibatok II Kecamatan Cibungbulang Kabupaten Bogor. Beberapa individu serangga uji yang digunakan sebagai populasi awal diidentifikasi untuk memastikan spesies. Proses identifikasi diawali dengan membuat preparat sementara. Pembuatan preparat slide mengacu pada Mound \& Kibby (1998) dan identifikasi dilakukan berdasarkan kunci identifikasi dari Sartiami \& Mound (2013).

Sebanyak 30 individu imago betina dan jantan hasil koleksi dari lapang dipelihara pada daun cabai umur 30 HST dalam kurungan serangga terbuat dari gelas plastik $(\mathrm{d}=4 \mathrm{~cm}$ dan $\mathrm{t}=8 \mathrm{~cm})$. Permukaan bagian atas dibuat lubang ventilasi dilapisi kain kasa organdi. Bagian bawah kurungan dilapisi tisu yang telah dibasahi. Tisu yang dibasahi bertujuan untuk menjaga kelembaban yang sesuai bagi perkembagan stadia prapupa dan pupa. Setiap kurungan diinfestasikan 1 individu imago betina dan jantan. Imago dikeluarkan dan dipindahkan pada daun dan kurungan baru setelah 24 jam. Daun yang telah terinfestasi telur diamati hingga muncul nimfa instar ke-1. Perbanyakan terus dilakukan hingga jumlah serangga yang dibutuhkan cukup untuk pengujian.

\section{Pengamatan biologi dan statistik demografi $T$. parvispinus}

Sebanyak 50 individu nimfa instar ke-1 dengan populasi kohort hasil dari perbanyakan sebelumnya, dipelihara secara terpisah pada daun cabai dalam kurungan gelas plastik. Kohort merupakan kelompok individu yang lahir dalam interval waktu yang hampir sama (Begon et al. 2006). Setiap helai daun dalam kurungan diinfestasikan 1 individu nimfa instar ke-1. Daun cabai sebagai inang diganti setiap harinya. Jumlah nimfa yang hidup, mati, dan ganti kulit diamati dan dicatat perkembangannya setiap hari hingga imago. Pergantian instar ditandai dengan adanya eksuvia. Jenis kelamin imago yang muncul juga dicatat. Pengamatan dilakukan dengan menggunakan mikroskop portable dinolite AM 2111 Basic dan mikroskop stereo.

Pengamatan lama hidup imago jantan dan betina dilakukan secara terpisah. Lama hidup imago jantan diamati dengan menginfestasikan imago pada daun cabai dalam kurungan serangga. Setiap 1 helai daun dalam kurungan diinfestasikan 1 individu imago jantan. Pengamatan dilakukan setiap hari hingga imago jantan terakhir mati. Pengamatan stadium praoviposisi, stadium oviposisi, siklus hidup, fekunditas, dan lama hidup imago betina dilakukan dengan menginfestasikan imago betina pada daun cabai dalam kurungan serangga. Setiap 1 helai daun dalam kurungan diinfestasikan 1 individu imago betina. Setiap hari, imago betina dipindahkan pada daun cabai yang baru di dalam kurungan baru. Pemindahan tersebut dilakukan setiap hari hingga imago betina terakhir mati. Daun cabai yang telah diinfestasi imago betina pada hari sebelumnya diamati setiap hari hingga muncul nimfa instar ke-1. Mound \& Masumoto (2005) melaporkan bahwa 
inkubasi telur dapat berlangsung selama 3-7 hari. Berdasarkan hal tersebut pengamatan dilakukan setiap hari selama 7 hari. Pengamatan dilakukan dengan menggunakan mikroskop portable dinolite AM 2111 Basic dan mikroskop stereo.

\section{Analisis data}

Data hasil pengamatan kohort trips selama 1 generasi disusun dalam bentuk neraca kehidupan. Neraca kehidupan kohort merupakan neraca kehidupan yang mengikuti perkembangan kohort, yang dimulai dari kemunculan individu pertama sampai kematian individu terakhir yang bertahan hidup (Begon et al. 2006). Data-data yang dibutuhkan ialah (1) x adalah kelas umur kohort (hari), (2) $l_{X}$ adalah peluang hidup setiap individu pada umur $\mathrm{x}$, (3) $\mathrm{m}_{\mathrm{x}}$ adalah fekunditas per individu pada umur $\mathrm{x}$, (4) $l_{\mathrm{X}} \mathrm{m}_{\mathrm{X}}$ adalah banyaknya keturunan yang dilahirkan pada kelas umur $\mathrm{x}$. Data diolah dan dianalisis dengan menggunakan Microsoft Office Excel 2010 Worksheet.

Penghitungan dilanjutkan dengan menggunakan metode Jackknife, yaitu teknik penghitungan dengan membuang satu data pengamatan secara berulang-ulang (resampling), kemudian berdasarkan gugus data baru tersebut, dihitung bias dan ragam statistiknya. Metode Jackknife digunakan sebagai pendekatan umum untuk melakukan uji hipotesis dan menghitung selang kepercayaan. Adapun parameter yang diamati, yaitu (1) Laju reproduksi kotor $(\mathrm{GRR})=\Sigma \mathrm{m}_{\mathrm{X}}$, (2) laju reproduksi bersih $\left(\mathrm{R}_{0}\right)=\Sigma l_{\mathrm{X}} \mathrm{m}_{\mathrm{X}}$, (3) laju pertumbuhan intrinsik $(r)=\ln \left(\mathrm{R}_{0}\right) / \mathrm{T}$, (4) rataan masa generasi $(\mathrm{T})=\sum \mathrm{xl}_{\mathrm{X}} \mathrm{m}_{\mathrm{X}} / \sum \mathrm{l}_{\mathrm{X}} \mathrm{m}_{\mathrm{X}}$ dan (5) populasi berlipat ganda $(\mathrm{DT})=\ln (2) / \mathrm{r}$.

\section{HASIL}

\section{Karakter morofologi T. parvispinus}

Pada bagian kepala terdapat dua pasang seta oseli, seta oseli III muncul pada garis segitiga oseli dengan ukuran yang lebih panjang dari seta oseli II (Gambar 1A). Antena terdiri atas VII ruas, ruas keIII dan ke-IV dengan sense cone yang berbentuk garpu, dan ruas ke-VII berukuran sangat kecil (Gambar 1B). Venasi pertama dan kedua sayap memiliki deretan seta yang lengkap (Gambar 1C). Pada toraks metanotum memiliki pola retikulasi medially (seperti kotak dengan ukuran yang serupa). Terdapat sepasang seta pada bagian tengah metanotum yang muncul di bawah garis atas metanotum (Gambar 1D). Tergit abdomen ruas ke-VIII tidak memiliki deretan microtrichia (Gambar 1E).

T. parvispinus jantan dan betina memiliki karakter morfologi yang berbeda. Imago $T$. parvispinus betina berwarna coklat dengan warna kepala dan toraks lebih pucat dibandingkan dengan warna abdomen (bicoloured) (Gambar 1F). Imago T. parvispinus jantan makroptera (bersayap), keseluruhan tubuhnya berwarna kuning (Gambar $1 \mathrm{G})$.

\section{Biologi T. parvispinus}

T. parvispinus memiliki tipe metamorfosis peralihan antara paurometabola dan holometabola. Tahap perkembangan terdiri atas telur, nimfa, prapupa, pupa, dan imago. Telur diletakkan secara tunggal di dalam jaringan epidermis daun. Telur berbentuk, seperti ginjal berwarna putih pucat dan berwarna semakin keruh ketika menetas (Gambar 2A).

Fase nimfa mengalami 2 kali pergantian kulit. Nimfa instar ke-1 berwarna putih transparan (Gambar 2B). Nimfa instar ke-2 berwarna kuning tua keruh yang semakin lama warnanya semakin kecoklatan (Gambar 2C). Prapupa dan pupa ditandai dengan adanya kerangka sayap dan merupakan fase inaktif. Prapupa memiliki kerangka sayap lebih pendek (sebatas toraks) yang berwarna putih transparan (Gambar 3A). Pupa memiliki kerangka sayap lebih panjang hingga abdomen. Kerangka sayap dan tungkai berwarna lebih gelap. Antena tertekuk ke belakang sepanjang kepala (Gambar 3B). Fase prapupa dan pupa umumnya berlangsung pada bagian bawah atau lipatan tisu.

Rataan masa perkembangan fase pradewasa atau stadium menjadi imago $T$. parvispinus berlangsung selama 12,97 dan 12,57 hari masingmasing pada jantan dan betina. Rataan siklus hidup imago betina berlangsung selama 13,68 hari dengan stadium praoviposisi berlangsung selama 1,1 hari. Lama hidup berlangsung selama 8,55 hari pada imago betina, dan 6 hari pada imago jantan (Tabel 1). Rasio kelamin jantan dibandingkan dengan betina T. parvispinus adalah $1: 1,63$. 

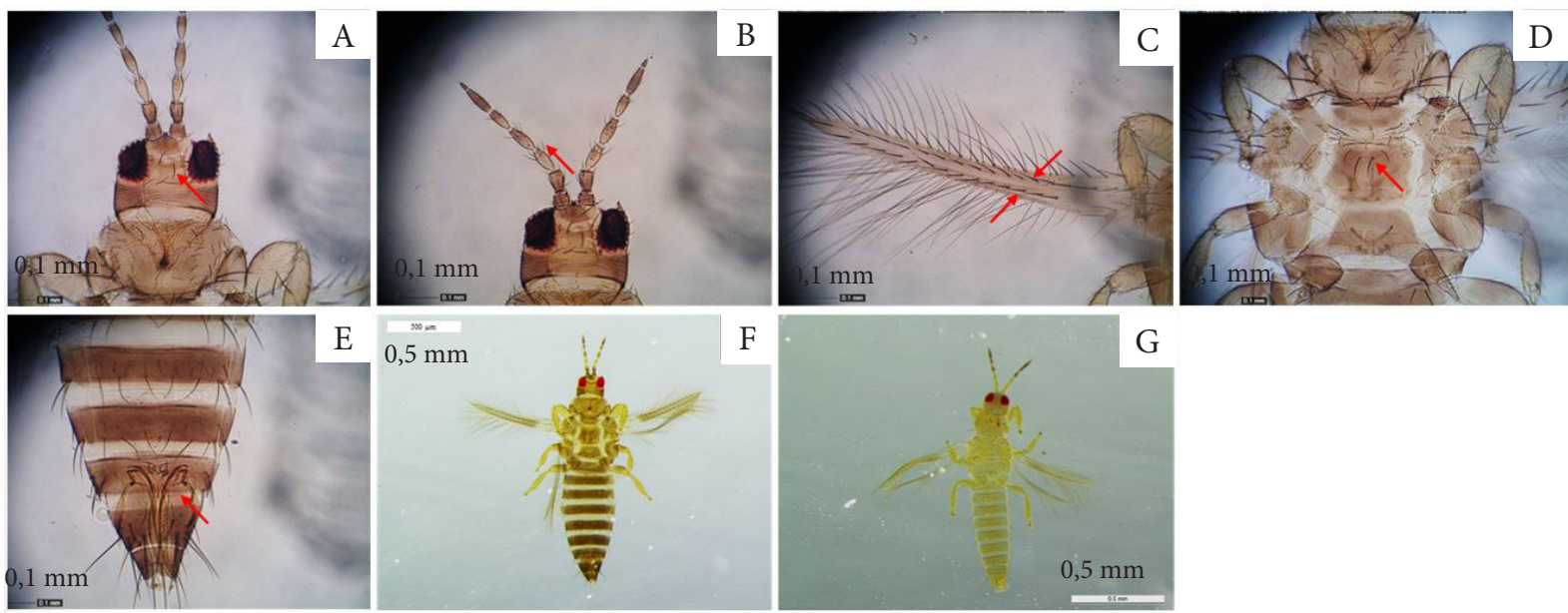

Gambar 1. Karakter morfologi Thrips parvispinus. A: kepala; B: antenna; C: sayap; D: metanotum; E: tergit abdomen ruas VIII; F: imago betina; dan G: imago jantan.
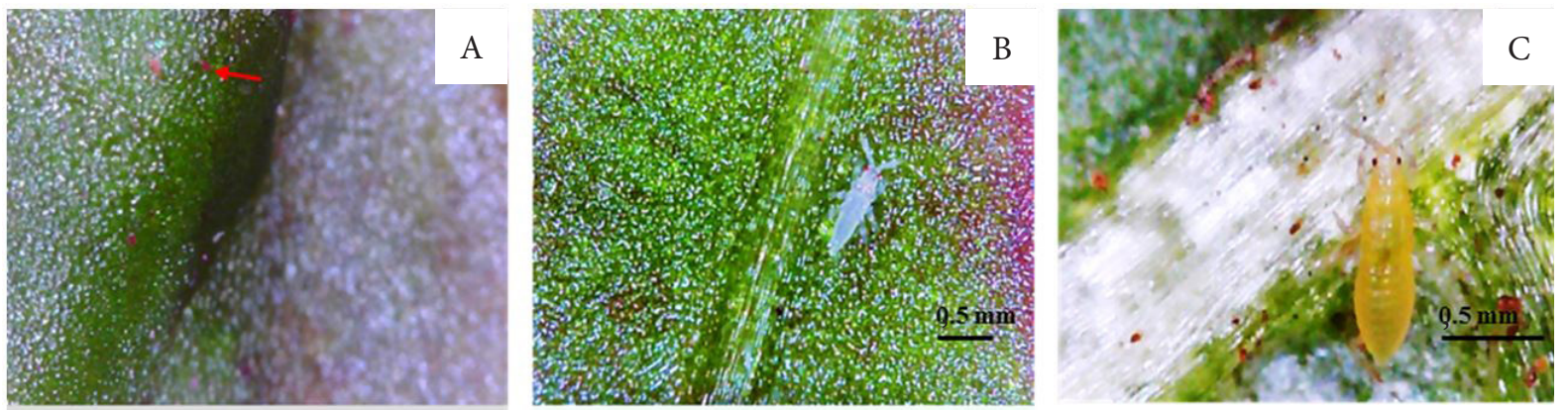

Gambar 2. Fase pradewasa Thrips parvispinus. A: telur; B: instar ke-1; dan C: instar ke-2.
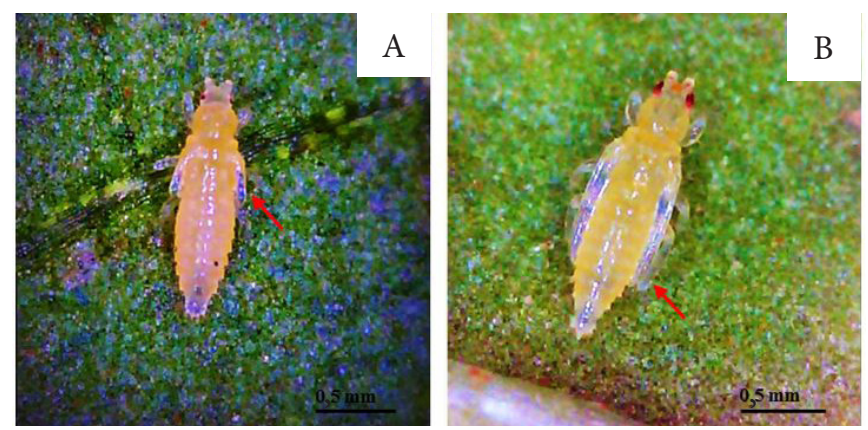

Gambar 3. Fase pradewasa dan imago Thrips parvispinus. A: prapupa; B: pupa.

\section{Sintasan dan keperidian T. parvispinus}

Peluang hidup T. parvispinus digambarkan dalam kurva sintasan $\left(1_{\mathrm{X}}\right)$, sedangkan natalitas $T$. parvispinus digambarkan dalam kurva keperidian $\left(\mathrm{m}_{\mathrm{X}}\right)$. Sintasan atau peluang hidup T. parvispinus diperoleh dari pengamatan harian mulai dari fase nimfa instar ke-1 hingga menjadi imago. Kurva sintasan T. parvispinus menggambarkan bahwa peluang hidup mulai menurun sejak individu berumur 2 hari setelah infestasi (Gambar 4). Kurva laju kesintasan dari hasil pengamatan menunjukkan tingkat kematian yang lebih banyak terjadi pada fase pradewasa atau dapat disebut kurva kesintasan tipe III.
Rataan telur yang mampu dihasilkan imago betina $T$. parvispinus dalam 1 generasi, yaitu sebanyak 15,33 telur per imago betina. Pada kurva rataan keperidian $\left(\mathrm{m}_{\mathrm{X}}\right)$, terlihat bahwa peletakan telur dimulai pada hari ke-9 sampai hari ke-24 setelah investasi. Imago betina trips meletakkan telur dalam jumlah sedikit pada awal fase imago dan jumlah terus bertambah seiring pertambahan umur imago dan kembali mengalamai fluktuasi hingga menjelang kematian imago. Dalam perkembangannya, rata-rata keperidian betina per hari mencapai titik maksimum pada hari ke-11 dengan jumlah telur 4,00 telur (Gambar 4). 
Tabel 1. Rataan lama stadia dan keperidian Thrips parvispinus pada tanaman cabai

\begin{tabular}{lcc}
\hline Fase & n (individu) & Rata-rata \pm SE (hari) \\
\hline Telur & 276 & $4,79 \pm 0,90$ \\
Instar-1 & 47 & $1,36 \pm 0,12$ \\
Instar-2 & 42 & $3,54 \pm 0,13$ \\
Prapupa & 35 & $1,08 \pm 0,06$ \\
Pupa & 29 & $1,96 \pm 0,07$ \\
Jantan & & \\
$\quad$ Stadium menjadi imago & 11 & $12,97 \pm 0,32$ \\
$\quad$ Lama hidup & 11 & $6,00 \pm 1,36$ \\
Betina & & \\
Stadium menjadi imago & 18 & $12,57 \pm 0,12$ \\
Praoviposisi & 18 & $1,11 \pm 0,07$ \\
Siklus hidup & 18 & $13,68 \pm 0,11$ \\
Lama hidup & 18 & $8,55 \pm 0,83$ \\
Keperidian (telur/imago betina) & 18 & $15,33 \pm 2,18$ \\
\hline
\end{tabular}

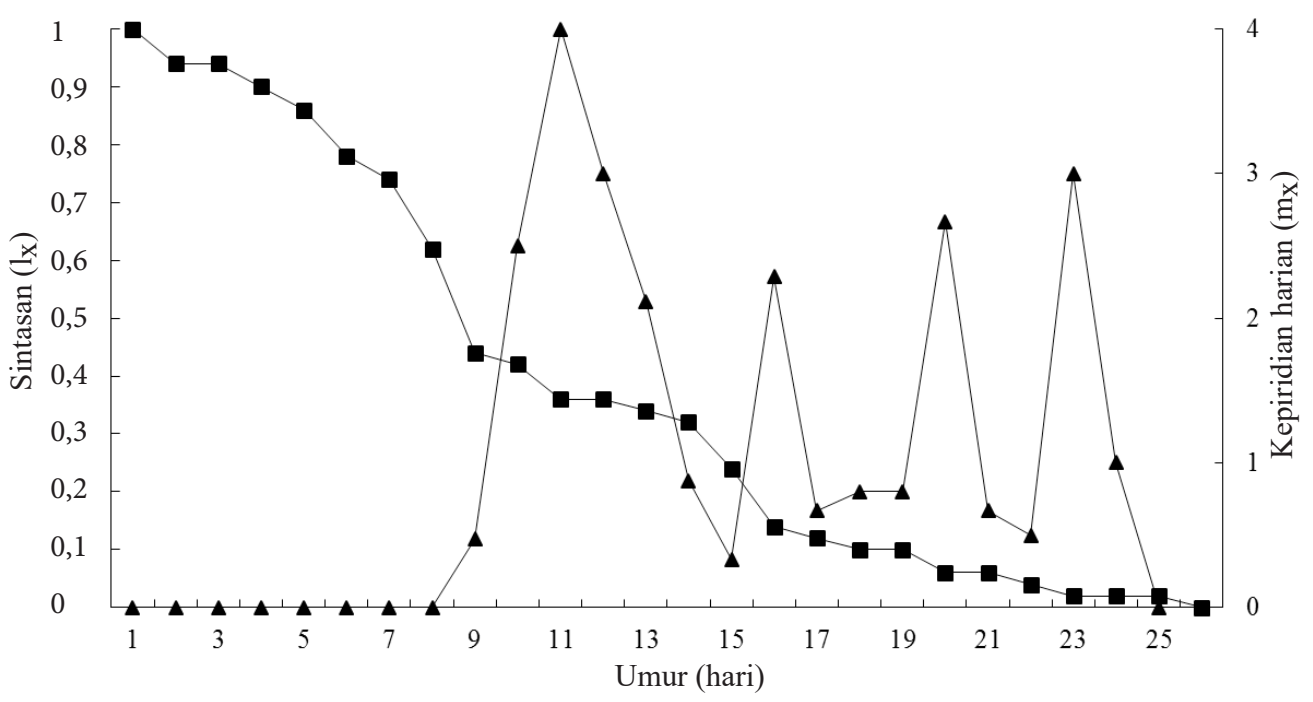

Gambar 4. Kurva sintasan $\left(\mathrm{l}_{\mathrm{X}}\right)(\boldsymbol{\square})$ dan keperidian $\left(\mathrm{m}_{\mathrm{X}}\right)(\boldsymbol{\Delta})$ Thrips parvispinus.

\section{Statistik demografi T. parvispinus}

Berdasarkan hasil pengamatan, seluruh imago betina T. parvispinus sepanjang generasi mampu menghasilkan rataan keturunan sebanyak 25,60 individu per generasi. T. parvispinus memiliki nilai reproduksi bersih $\left(\mathrm{R}_{0}\right)$ sebesar 5,71 individu betina per induk per generasi, rataan nilai laju pertambahan instrinsik $(r)$ sebesar 0,15 individu per induk per hari, dan rataan lama generasi selama 11,49 hari. Doubling time atau waktu yang dibutuhkan populasi $T$. parvispinus untuk berlipat ganda (DT) adalah 4,57 hari (Tabel 2).

\section{PEMBAHASAN}

T. parvispinus memiliki tipe metamorfosis peralihan antara paurometabola dan holometabola. Serangga ini tergolong dalam tipe peralihan karena mengalami lebih dari satu instar pradewasa yang memiliki kerangka sayap, perkembangan sayap yang terjadi pada bagian dalam, dan fase inaktif (pupa) sebelum menjadi imago (Borror et al. 2005).

Rataan masa perkembangan fase pradewasa atau waktu yang dibutuhkan sampai menjadi imago T. parvspinus berlangsung singkat. Hal 
Tabel 2. Parameter demografi Thrips parvispinus

\begin{tabular}{lc}
\hline Parameter & Rata-rata $\pm \mathrm{SE}$ \\
\hline Laju reproduksi kotor (GRR) & $25,60 \pm 0,14$ individu/generasi \\
Laju reproduksi bersih $\left(\mathrm{R}_{0}\right)$ & $5,71 \pm 0,02$ individu/induk/generasi \\
Laju pertambahan intrinsik $(\mathrm{r})$ & $0,15 \pm 0,00$ individu/induk/hari \\
Rataan lama generasi (T) & $11,49 \pm 0,01$ hari \\
Waktu berlipat ganda (DT) & $4,57 \pm 0,12$ hari \\
\hline
\end{tabular}

ini diduga dipengaruhi oleh kesesuaian serangga terhadap tanaman inang serta kondisi suhu dan kelembapan saat pemeliharaan. Pertumbuhan dan perkembangan populasi serangga ditentukan oleh faktor luar (faktor eksternal) dan faktor serangga itu sendiri (faktor internal). Salah satu faktor eksternal, yaitu suhu dan kelembaban yang sangat berkaitan terhadap iklim mikro perkembangan populasi serangga. Zhang et al. (2007) melaporkan bahwa, rataan masa perkembangan Frankliniella occidentalis (Pergande) dari pradewasa sampai menjadi imago berlangsung selama 12,15 hari pada tanaman cabai di laboratorium dengan suhu $\pm 27^{\circ} \mathrm{C}$. Rataan masa perkembangan Thrips palmi Karny dari telur sampai menjadi imago dilaporkan berlangsung selama 10,5 hari pada tanaman mentimun di laboratorium dengan suhu $\pm 27,5{ }^{\circ} \mathrm{C}$ dan kelembaban relatif $\pm 60 \%$ (Park et al. 2010).

Stadium praoviposisi merupakan selang waktu ketika imago betina pertama kali muncul hingga peletakan telur. Stadium praoviposisi $T$. parvispinus berlangsung singkat, yaitu rata-rata selama 1,1 hari (Tabel 1). Masa praoviposisi yang singkat akan mempercepat proses peletakan telur yang pertama. Hasil penelitian Zhang et al. (2007) menunjukkan bahwa stadium praoviposisi F. occidentalis berlangsung selama 1,67 hari pada tanaman cabai dengan suhu $\pm 27^{\circ} \mathrm{C}$. Salmasi et al. (2003) melaporkan bahwa pada suhu $\pm 27^{\circ} \mathrm{C}$ stadium praoviposisi Thrips tabaci Lind. pada tanaman bawang berlangsung selama 3,60 hari.

Stadium pradewasa yang singkat secara tidak langsung menyebabkan siklus hidup imago T. parvispinus menjadi lebih pendek. Menurut Amarasekare et al. (2008), perbedaan siklus hidup serangga pada beberapa tanaman inang dapat disebabkan oleh faktor nutrisi, senyawa alelokimiawi, dan struktur fisik daun tanaman inang. Spesies tanaman yang berbeda menyediakan kualitas nutrisi dan unsur pokok kimia yang berbeda. Hal itu dapat memengaruhi karakteristik suatu populasi terutama terhadap perkembangan, tingkat reproduksi, dan ketahanan serangga tersebut.

Lama hidup diukur berdasarkan selang waktu sejak imago pertama kali muncul hingga imago tersebut mati. Serangga yang hidup pada pakan yang relatif sesuai, pertumbuhan dan perkembangannya akan berlangsung lebih baik dan sesuai dengan pertumbuhan serangga secara normal. Rataan lama hidup F. occidentalis dilaporkan berlangsung selama 4 hari (jantan), dan 8,23 hari (betina) pada tanaman cabai pada suhu $\pm 27^{\circ} \mathrm{C}$ (Zhang et al. 2007). Salmasi et al. (2003) melaporkan bahwa, pada rataan suhu $27{ }^{\circ} \mathrm{C}$, lama hidup imago betina T. tabaci pada tanaman bawang berlangsung selama 16,15 hari.

Nisbah kelamin merupakan jumlah relatif jantan dan betina dalam suatu populasi. Semakin banyak betina yang dihasilkan maka semakin cepat populasi serangga tersebut berkembang. Rasio jenis kelamin jantan dan betina T. parvispinus, yaitu $1: 1,63$. Menurut Graham \& Knight (1967), kualitas pakan yang cukup banyak, daya reproduksi betina yang tinggi, serta spesies partenogenesis akan cenderung menghasilkan serangga betina yang lebih banyak.

Mortalitas yang tinggi pada fase pradewasa menghasilkan kurva laju kesintasan tipe III. Menurut Price (1997) terdapat 3 jenis kurva bertahan hidup. Kurva tipe I menggambarkan kematian organisme dalam jumlah sedikit ketika populasi berumur muda dan kematian dalam jumlah besar sewaktu populasi berumur lebih tua. Tipe II menunjukkan laju kematian yang konstan, dan tipe III memperlihatkan kematian yang lebih banyak pada populasi berumur muda. Waktu terjadinya kematian yang tinggi memiliki peran penting dalam suatu populasi. Populasi dengan kematian yang tinggi pada saat pradewasa 
memiliki struktur yang berbeda dari populasi dengan kematian yang tinggi saat dewasa. Kematian individu saat pradewasa yang tinggi mengakibatkan tingkat populasi yang lebih rendah pada generasi berikutnya dibandingkan dengan kematian yang tinggi saat dewasa (Listihani 2015).

Nilai rata-rata $\mathrm{R}_{0} T$. parvispinus sebesar 5,71 betina per induk per generasi menunjukkan bahwa populasi $T$. parvispinus dapat berlipat ganda sebanyak 5,71 kali dalam setiap generasinya. $\mathrm{R}_{0}$ merupakan jumlah individu betina yang akan dihasilkan oleh setiap imago betina di dalam populasi. Nilai $R_{0}$ dipengaruhi oleh jumlah keturunan yang dihasilkan per imago betina dan peluang hidup imago betina. Laju pertambahan intrinsik pada lingkungan konstan dan keadaan sumber daya yang tidak terbatas digambarkan dengan nilai r. Laju pertambahan intrinsik ditentukan oleh berbagai aspek yang berhubungan dengan siklus kehidupan organisme tersebut, yaitu kematian, kelahiran, dan waktu perkembangan. Nilai $r$ sebesar 0,15 menunjukkan bahwa populasi dalam kondisi yang tidak terbatas, individu dalam populasi dapat bertambah sebanyak 0,15 kali atau percepatan pertambahannya sebesar $15 \%$ individu per hari. Tinggi rendahnya nilai $r$ dapat dipengaruhi oleh keperidian, mortalitas pradewasa, dan masa dewasa.

Nilai rata-rata $T$ merupakan nilai lama generasi. Nilai T yang semakin kecil menunjukkan semakin cepat suatu organisme untuk berkembangbiak. Nilai DT yang tinggi dapat menyebabkan meningkatnya laju reproduksi kotor atau gross reproduction rate (GRR) dan nilai $\mathrm{R}_{0}$ dalam satuan waktu tertentu. Nilai DT yang rendah menunjukkan semakin singkat waktu yang dibutuhkan populasi untuk berlipat ganda. Hasil penelitian Zhang et al. (2007) pada tanaman cabai menunjukkan bahwa $\mathrm{R}_{0}$, $\mathrm{r}$, dan $\mathrm{T} F$. occidentalis masing-masing sebesar 1,34 individu per generasi, 0,17 individu per induk per hari, dan 16,19 hari dengan rataan suhu sebesar $27^{\circ} \mathrm{C}$.

\section{KESIMPULAN}

Stadia pradewasa T. parvispinus terdiri atas 5 fase, yaitu telur, nimfa instar ke-1, nimfa instar ke2, prapupa, dan pupa. Stadium telur berlangsung selama 4,79 hari, nimfa instar ke-1 selama 1,36 hari, nimfa instar ke-2 selama 3,54 hari, prapupa selama 1,08 hari, dan pupa selama 1,96 hari. Siklus hidup berlangsung selama 13,68 hari dengan stadium praoviposisi selama 1,11 hari. Lama hidup betina berlangsung selama 8,55 hari, sedangkan jantan berlangsung selama 6,00 hari. Rataan keperidian sebanyak 15,33 telur per imago betina sepanjang generasi. Tipe perkembangan populasi T. parvispinus termasuk dalam kurva sintasan tipe III, artinya tingkat kematian lebih banyak terjadi pada fase pradewasa. Statistik demografi $T$. parvispinus pada tanaman cabai, antara lain GRR sebanyak 25,60 individu per generasi, $R_{0}$ sebanyak 5,71 individu per induk per generasi, $\mathrm{r}$ sebesar 0,15 individu per induk per hari, rata-rata $T$ selama 11,49 hari, dan waktu berlipat ganda selama 5,57 hari.

\section{UCAPAN TERIMA KASIH}

Penulis mengucapkan terima kasih kepada program Beasiswa Pendidikan Pascasarjana dalam Negeri (BPPDN), Direktorat Jenderal Pendidikan Tinggi-Kementerian Ristek dan Pendidikan Tinggi yang sudah mendanai penelitian ini.

\section{DAFTAR PUSTAKA}

Amarasekare KG, Mannion CM, Osborne LS. 2008. Life history of Paracoccus marginatus (Hemiptera: Pseudococcidae) on four host plant spesies under laboratory condition. Environmental Entomology 37:630-635. doi: https://doi.org/10.1603/0046-225X(2008)37[63 $0:$ LHOPMH]2.0.CO;2.

Antonelli LA. 2003. Thrips. Washington: Washington State University (WSU) Puyallup; Tersedia pada: www.puyallup.wsu.edu/plantclinic/resources/ pdf/pls36thrips.pdf. [diakses 20 Juni 2015]. Begon M, Townsend CR, Harper JL. 2006. Ecology: From Individuals to Ecosystems. $4^{\text {th }}$ ed. Oxford: Blackwell Publishing.

Borror DJ, Triplehorn CA, Johnson NF. 1996. Pengenalan Pelajaran Serangga. Ed ke-6. Partosoedjono, penerjemah. Yogyakarta: Gajah Mada University Pr. Terjemahan dari: An Introduction to the Study of Insects. 
Borror DJ, Triplehorn CA, Johnson NF. 2005. An Introduction to The Studies of Insects. $7^{\text {th }}$ ed. United States of America: Brooks/Cole.

Carey JR. 2001. Insect biodemography. Annual Review of Entomology 46:79-110. https://doi. org/10.1146/annurev.ento.46.1.79.

Funderburk J. 2001. Ecology of thrips. Di dalam: Marullo R, Mound L, (Eds). Thrips and Tospoviruses. Proceedings of the 7th International Symposium on Thysanoptera. (Reggio Calabria, 2-7 Juli 2001). pp. 121-128. Canberra: CSIRO Entomology.

Graham SA, Knight FB. 1967. Principles Of Forest Entomology. New York: McGrawHill Book Company.

Kalshoven LGE. 1981. The Pests of Crops in Indonesia. Lan PA van der, penerjemah. Jakarta: Ichtiar Baru-van Hoeve. Terjemahan dari: De Plagen van de Cultuurgewasseng in Indonesia.

Kirk WDJ. 2001. The pest and vector from the west: Frankliniella ocidentalis. Di dalam: Rita M, Laurence M. (Eds.). Thrips and Tospoviruses. Proceedings of the 7th International Symposium on Thysanoptera (Reggio Calabria 2-7 Juli 2001). pp. 33-42. Canberra: CSIRO Entomology.

Klose MJ, Sdoode R, Teakle DS, Milne JR, Greber RS. 1996. Transmission of three strains of Tobacco streak ilarvirus by different thrips species using virus-infected pollen. Journal of Phytopathology 144:281-284. doi: https://doi. org/10.1111/j.1439-0434.1996.tb01530.x.

Lewis T. 1973. Thrips: Their Biology, Ecology, and Economic Importance. London: Academic Press.

Lewis T. 1997. Pest thrips in perspective. Di dalam: Lewis T (Eds.). Thrips and Crop Pest. pp.1-13. Cambridge: CABI.

Listihani. 2015. Dampak Aplikasi PGPR pada Kacang Panjang terhadap Biologi dan Statistik Demografi Aphis craccivora Koch (Hemiptera: Aphididae). Skripsi. Bogor: Institut Pertanian Bogor.

Mound LA. 2006. Taxonomy of the insect order Thysanoptera. Thrips. Di dalam: Taxonomy Workshop No.1 (Kuala Lumpur 3-7 Juli 2006). Kuala Lumpur: Institute of Biological Science, University Malaya Kuala Lumpur.

Mound LA, Collins DW. 2000. A Southeast Asian pest species newly recorded from Europe: Thrips parvispinus (Thysanoptera: Thripidae), its confused identity and potential quarantine significance. European Journal of Entomology 97:197-200. doi: https://doi.org/10.14411/eje.2000.037.
Mound LA, Kibby G. 1998. Thysanoptera An Identification Guide. $2^{\text {nd }}$ ed. Canberra: CSIRO Entomology.

Mound LA, Masumoto M. 2005. The genus Thrips (Thysanoptera, Thripidae) in Australia, New Caledonia and New Zealand. Zootaxa 1020:1-64. doi: https://doi.org/10.11646/zootaxa.1020.1.1.

Park CG, Kim HY, Lee JH. 2010. Parameter estimation for a temperature-dependent development model of Thrips palmi Karny (Thysanoptera: Thripidae). Journal of AsiaPacific Entomology 13:145-149. doi:https://doi. org/10.1016/j.aspen.2010.01.005.

Prabaningrum L. 2005. Biologi dan Sebaran Populasi Thrips sp. (Thysanoptera:Thripidae) pada Tanaman Paprika. Disertasi. Bandung: Universitas Padjajaran.

Price PW. 1997. Insect Ecology. $3^{\text {th }}$ ed. New York: John Wiley \& Sons.

Rezende JAM, Galleti SR, Pozzer L, Resende RO, de Avila AC, Scagliusi SMM. 1997. Incidence, biological, and serological characteristicts of a Tospovirus in experimental fields of zucchini in Sao Paulo state, Brazil. Fitopatología Brasileira 22:92-95.

Riley DG, Joseph SV, Srinivasan R, Diffie S. 2011. Thrips vectors of Tospovirus. Journal of Integrated Pest Management 1:1-10. doi: https:// doi.org/10.1603/IPM10020.

Rockwood LL. 2006. Introduction to Population Ecology. Malden: Blackwell Publishing.

Salmasi H, Hejazi M, Rahnemon AA. 2003. Life cycle of onion thrips, Thrips tabaci Lind. in insectarium. Journal of Agricultural Science 13:91-100.

Sartiami D. 2008. Kunci identifikasi Ordo Thysanoptera pada tanaman pangan dan hortikultura. Jurnal Ilmu Pertanian Indonesia 13:103-110.

Sartiami D, Mound LA. 2013. Identification of the terebrantian thrips (Insecta, Thysanoptera) associated with cultivated plants in Java, Indonesia. ZooKeys 306:1-21. doi: https://doi. org/10.3897/zookeys.306.5455.

Sastrosiswojo S. 1991. Thrips on vegetables in Indonesia. Di dalam: Talekar NS (Eds.). Thrips in Southeast Asia. Proc. Regional Consultation Workshop (Bangkok, 13 March 1991). pp. 1217. Taiwan: AVRDC.

Vos JGM. 1991. Thrips on vegetables in Indonesia. Di dalam: TalekarNS(Eds.) Thrips in Southeast Asia. Proc. Regional Consultation Workshop (Bangkok 13 March 1991). pp. 12-17. Taiwan: AVRDC. 
Zhang ZJ, Wu QJ, Li XF, Zhang YJ, Xu BY, Zhu GR. 2007. Life history of western flower thrips, Frankliniella occidentalis (Thysan., Thripae), on five different vegetable leaves. Journal of Applied Entomology 131:347-354. doi: https:// doi.org/10.1111/j.1439-0418.2007.01186.x. 